\title{
Short Communication: \\ Presence of the vulnerable freshwater goby Sicyopus auxilimentus (Gobiidae, Sicydiinae) on Sangihe Island, Indonesia
}

\author{
VERYL HASAN ${ }^{1,2, \bullet}$, FITRI SIL VALEN ${ }^{2}$, R. ADHARYAN ISLAMY ${ }^{3}$, MAHENO SRI WIDODO ${ }^{3, v "}$, \\ ADITYA MIRZAPAHLEVI SAPTADJAJA ${ }^{4}$, IZZUL ISLAM ${ }^{5}$ \\ ${ }^{1}$ Department of Fish Health Management and Aquaculture, Faculty of Fisheries and Marine, Universitas Airlangga. Jl. Dr. Ir. Sukarno, Surabaya 60115, \\ East Java, Indonesia. Tel./fax.: +62-31-5911451, "email: veryl.hasan@ fpk.unair.ac.id \\ ${ }^{2}$ Division of Zoology, Generasi Biologi Indonesia Foundation. Jl. Swadaya Barat No. 4, Gresik 61171, East Java, Indonesia. \\ ${ }^{3}$ Department of Aquaculture, Faculty of Fisheries and Marine Science, Universitas Brawijaya. J1. Veteran, Malang 65145, East Java, Indonesia. \\ Tel.: +62-341-553512, "wemail: maheno2019@gmail.com \\ ${ }^{4}$ Greenaration Foundation. Jl. Citamiang No. 6, Bandung 40121, West Java, Indonesia \\ ${ }_{5}^{5}$ Department of Bioctechnology, Faculty of Technobiology, Universitas Teknologi Sumbawa. Jl. Raya Olat Aras, Sumbawa 84371, West Nusa Tenggara, \\ Indonesia
}

Manuscript received: 12 November 2020. Revision accepted: 8 January 2021

\begin{abstract}
Hasan V, Valen FS, Islamy RA, Widodo MS, Saptadjaja AM, Islam I. 2021. Short Communication: Presence of the vulnerable freshwater goby Sicyopus auxilimentus (Gobiidae, Sicydiinae) on Sangihe Island, Indonesia. Biodiversitas 22: 571-579. A single specimen of freshwater goby Sicyopus auxilimentus was photographed and collected using fish traps between 8 and 15 September 2019 in the Laine waterfall, Sangihe island district, North Sulawesi Province, Indonesia. S. auxilimentus is amphidromous that live in both freshwater and marine environments. This species is currently listed as Vulnerable (VU) within the IUCN Red List Status. The specimen was identified as male $S$. auxilimentus based on the coloration of the preserved specimen: background yellowish; scale edges brown; posterior flanks and caudal peduncle orange; first dorsal fin black, second dorsal fin dusky black; pectoral fin slightly brown; ventral fin slightly dusky; anal fin blackish; caudal fin dusky brown. Specific morphological features were as follows: the base of the first dorsal fin was not connected to the second dorsal fin base; distance between the base of first and second dorsal fin was generally less than half of eye diameter; ventral fin rays were fused to belly only between fifth rays; posterior margin of caudal fins rays was rounded; scales were all ctenoid; scales appeared on the caudal peduncle, and between anal and second dorsal fins; anterior to which, scales became widely spaced and did not imbricate. Meristic characters were as follows: first dorsal fin rays VI; second dorsal fin rays I+9; ventral fin rays I+5; pectoralfin rays 14; anal-fin rays I+9; caudal-fin rays 13; scales in lateral series 13; scales in zigzag series 7; scales in transverse series backward 7; scales in transerves series forward 4. This finding is considered the first record in Sulawesi and the fifth from Indonesian waters after findings in Halmahera, Java, Bali and Lombok. This record enhances the understanding of the distribution of S. auxilimentus in Indonesian waters. Monitoring is needed to assess the possibility of Sangihe Island being a growth ground, spawning ground, and/or on the migration route of S. auxilimentus. In the Laine waterfall, Sangihe island, freshwater conditions were as follows: salinity 3.5 psu, temperature $23-$ $25^{\circ} \mathrm{C}$, and dissolved oxygen $7.7-9.2 \mathrm{mg} / \mathrm{l}$, which were ideal habitat for S. auxilimentus. S. auxilimentus from Sangihe Island, had 0.000 genetic distance than from $S$. auxilimentus from Bali, while the next closest genetic distance was $S$. zosterophorus at genetic distance of 0.090. In addition to onsite conservation, domestication programs are needed to increase commercial availability without depending on natural catches.
\end{abstract}

Keywords: Biogeography, distribution, freshwater goby, vulnerable

\section{INTRODUCTION}

The family Gobiidae (Gill and Mooi 2012; Taillebois et al. 2013; Taillebois et al. 2014) consists of more than 1700 goby species in more than 200 genera inhabiting brackish, marine, and freshwaters (Murdy 2011a; Murdy 2011b; Pezold 2011; Thacker 2011; Thacker and Roje 2011). Gobies are one of the most diverse groups of vertebrates in the world, second only to the Cyprinidae (Patzner 2011; Tornabene et al. 2013). They greatly contribute to the diversity seen in a number of aquatic habitats, including oceanic island streams (Keith et al. 2006; Keith et al. 2015). The Sicydiinae goby is associated with various river or nearshore habitats not only because of the physical habitat that may offer protection or favorable conditions for their physiology but also because those habitats provide sources of nutrients such as microbenthos, zooplankton, periphyton, and phytoplankton (Hoareau et al. 2012; Boseto et al. 2016; Christoffersen et al. 2019). Estuarine, freshwaters, and bays have been considered important habitats for different life cycle stages of Sicydiinae. These areas often have high productivity, serving as a potential spawning ground and migration route (Taillebois et al. 2012; Iida et al. 2015; Cloern 2018; Islamy and Hasan 2020). Adult Sicydiinae goby can be found in tropical freshwaters in the Indo-Pacific, where they greatly contribute to the diversity of the freshwater fish communities (Lord et al. 2010; Teichert et al. 2013; Ellien et al. 2014). One of the genera from the family of Sicydiinae goby which is the amphidromous fish is 
Sicyopus (Watson and Kottelat 1994; Keith et al. 2014a).

Sicyopus are distributed in tropical and subtropical freshwater streams from Fiji, the South Pacific region to the eastern coast of Madagascar, Western Indian Ocean (Watson et al. 2007; Keith et al. 2014b). Sicyopus spawn in freshwaters, where the free embryos drift downstream to the sea where they undergo a planktonic phase in the offshore, before returning to the rivers to grow and reproduce (Keith 2003a; McDowall 2007). This marine pelagic larval phase varies between 91 and 265 days, and it is believed to be essential in explaining the spatial and temporal patterns of dispersal (Keith 2003b; Yamasaki and Tachihara 2006; Taillebois et al. 2014). It is assumed to be amphidromous as the other members of the subfamily (Keith et al. 2009; Keith and Lord 2011). This assumption arises from their physiology where the pelvic fins are modified into sucker disks, the soft parts and teeth associated with the jaws and jaw's suspensorium modifications (Harrison 1989; Parenti and Maciolek 1993; Watson 1995; Keith and Lord 2011). These characteristics have facilitated the ability of amphidromous gobies to ascend waterfalls to exploit high island streams (Keith and Lord 2011; Keith et al. 2011b). Many Sicydiine gobies are considered to be rare or endemic to specific regions, but some are wide-spread (Keith et al. 2005; Keith et al. 2014a; Keith and Hadiaty 2014).

The amphidromous nature of Sicyopus also indicates that they are sensitive to environmental changes, even of slight impact (Yamasaki and Tachihara 2006; Keith et al. 2009; Thuesen et al. 2011). Overall, it is generally believed that many Sicyopus are highly vulnerable or in high risk of extinction in the wild (Keith 2003a; Walter et al. 2012). One of the vulnerable species of this genus is $S$. auxilimentus (Watson and Kottelat 1994). This species is categorized as Vulnerable (VU) by the IUCN because their habitats are located near human settlements (Kottelat 1996). S. auxilimentus was recorded in the Indo-Pacific regions, including the Ryuku Islands, Amami-Oshima and Okinawa in Japan (Suzuki et al. 2009), Taiwan (Lin 2007), Leyte island and Cebu in the Philippines (Watson and Kottelat 1994; Chen and Shao 1998), and Halmahera (Watson and Kottelat 2006), Java, Lombok and Bali in Indonesia (Keith et al. 2015). Although the knowledge about $S$. auxilimentus and its distribution has been increasing since the last decades, the full extent of its range in some regions remain unclear, especially in Indonesia. We report the presence of $S$. auxilimentus in the Sangihe island, North Sulawesi, Indonesia, which documents an extension of the known distribution range for this species. The movement and migration patterns of $S$. auxilimentus in time and space are fundamental to the study of its habitat ecology, interpreting of the influence of human activities on these species, and in design of effective resource management and conservation (Ebner et al. 2011; Keith et al. 2015; Boseto et al. 2016).

Currently, the studies and the confirmation of species are no longer only based solely on morphological data. Researchers increasingly combine morphological and molecular data as well as, environmental, geographical, and behavioral data to refine and improve species delineation
(Padial et al. 2010; Keith et al. 2011a). The molecular barcoding approach using Cytochrome c oxidase I (COI) has been classically used (Ratnasingham and Hebert 2007). Partial COI allows the genetic identification of species in numerous taxa. Divergence, which appeared by mutation over time, between different individual's sequences is low for individuals of the same species and high between individuals of a different species (Imtiaz et al. 2017; MdZain et al. 2018a; Md-Zain et al. 2018b; Roesma et al. 2019; Nuryanto et al. 2019). This paper also provides a description based on morphometric, meristic, and molecular data (COI) of $S$. auxilimentus from Sangihe Island, North Sulawesi, Indonesia.

\section{MATERIALS AND METHODS}

\section{Sampling site}

The site is in the Laine waterfall (Figure 1), Sangihe Island District, North Sulawesi Province, Indonesia $\left(3^{\circ} 25^{\prime} 52^{\prime \prime} \mathrm{N} ; 125^{\circ} 35^{\prime} 55^{\prime \prime} \mathrm{E}\right)$, about $0.5 \mathrm{~km}$ away from the mouth of the river. The site is located in an area used for tourism and nearby fishery activities. Sangihe Island is a remote island in the Sulawesi (Celebes) Sea and bordered by Philippines.

\section{Fish collection and water quality}

Fish collection could be freely carried out without special permits, but the locals prohibit the use of nonenvironmentally friendly fishing gear (Kolding and van Zwieten 2014; Hasan and Widodo 2020). Four fish traps with a size of $90 \times 90 \times 40 \mathrm{~cm}^{3}$, made of wire and mesh with dimension of $3 \mathrm{~cm}$ were used in this study. The study was conducted from 8 to 15 September 2019 with two traps deployed at each of two different depths, of $0.5 \mathrm{~m}$ and 0.8 $\mathrm{m}$ of the river bottom. The traps were left for one week, and checked daily for trapped fish. Fish caught were collected from all four traps and brought to the laboratory for the next step. The water quality parameters included salinity (psu), temperature $\left({ }^{\circ} \mathrm{C}\right)$, and dissolved oxygen $(\mathrm{mg} / \mathrm{l})$, were determined in situ at each location immediately after capture events.

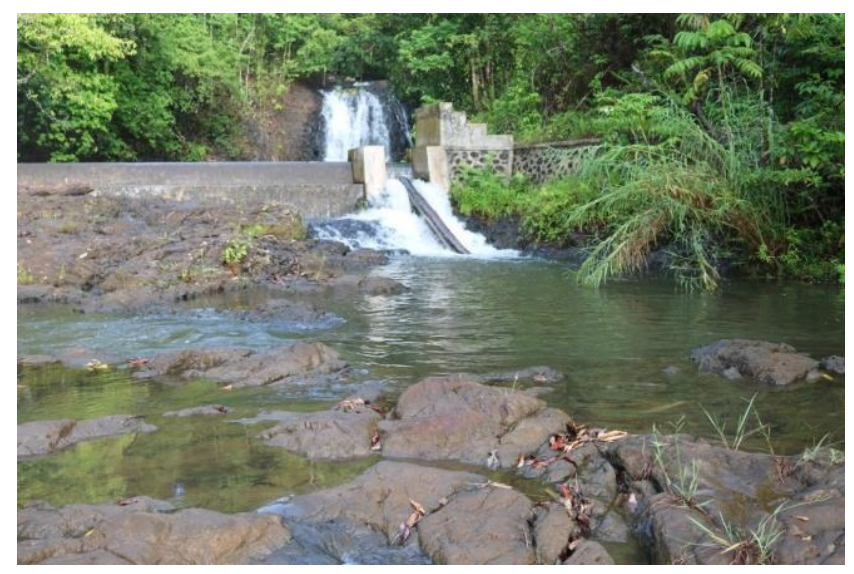

Figure 1. Laine river, location where $S$. auxilimentus found in Sangihe Island, North Sulawesi, Indonesia 


\section{Preserve fish and identification}

Sicyopus auxilimentus were killed before the identification. Fish killing is considered an ethical treatment of a live fish that will be used for scientific purposes (Wall 2001; Metcalfe and Craig 2011). The pectoral fin on the right body was cut for DNA extraction. The right side was chosen for this and other similar operations, such as the removal of scale samples, because the left side was used to obtain morphometric data and is commonly shown in photographs. The collected specimen was labeled and fixed in $96 \%$ alcohol solution (Hasan and Tamam 2019). Materials examined were deposited at the zoology laboratory, Generasi Biologi Indonesia Foundation (GBI0044). Diagnostic morphological characters of the specimen were analyzed following Watson and Kottelat (1994) and Keith et al. (2015). The determined meristic characters include the first dorsal fin rays, second dorsal fin rays, ventral fin rays, pectoral fin rays, anal fin rays, caudal fin rays, scales in lateral series, scales in zigzag series, scales in transverse series backward, and scales in transverse series forward. Meristic characters of specimen were measured using digital calipers to the nearest $0.1 \mathrm{~mm}$.

\section{DNA extraction, isolation, and amplification}

The sample extraction of DNA used the Genomic DNeasy Blood \& Qiagen Tissue Kit. Amplification of cytochrome C oxidase subunit I (COI) gene was conducted with the AmplyTaq RedTM (Applied Biosystems) and the universal fish DNA-Barcoding primers Fish_F1 and Fish_R1 (Ward et al. 2005).

Fish F1-5'TCAACCAACCACAAAGACATTGGCAC3'; Fish R1-5'TAGACTTCTGGGTGGCCAAAGAATCA3'.

The temperature profile at the time of amplification included: initial denaturation of $94^{\circ} \mathrm{C}$ for three minutes, 35 cycles of $94^{\circ} \mathrm{C}$ for 30 seconds, $50^{\circ} \mathrm{C}$ for 30 seconds, and $72^{\circ} \mathrm{C}$ for 60 seconds, with a final extension of $72^{\circ} \mathrm{C}$ for two minutes. The PCR results were then visualized in $1 \%$ agarose gel via electrophoresis by staining Nucleic Acid Gel Stain (GelRed®).

Species were identified by comparing the sequences to the GenBank NCBI (National Center for Biotechnology Information) via BLASTn (Basic Local Alignment Search Tool-nucleotide) method to analyze a sequence homology. The history of evolution was concluded using the Neighbor-Joining method (Saitou and Nei 1987; Ardura et al. 2010; Lakra et al. 2011) with a bootstrap test of 10000 replications (Felsenstein 1985) and the evolutionary distance was calculated using the p-distance method (Nei and Kumar 2000) in MEGA6 (Tamura et al. 2013).

\section{RESULTS AND DISCUSSION}

\section{New record}

Indonesia: Sulawesi: North Sulawesi Province: Sangihe Island: Tahuna District: Laine Waterfall: rapid and boulder-strewn streams with rocky bottoms, $\left(3^{\circ} 25^{\prime} 52^{\prime \prime N}\right.$; $\left.125^{\circ} 35^{\prime} 55^{\prime \prime} \mathrm{E}\right), 15$ October 2020 , single male specimen 7.9 $\mathrm{cm}$, adult male, photographed.

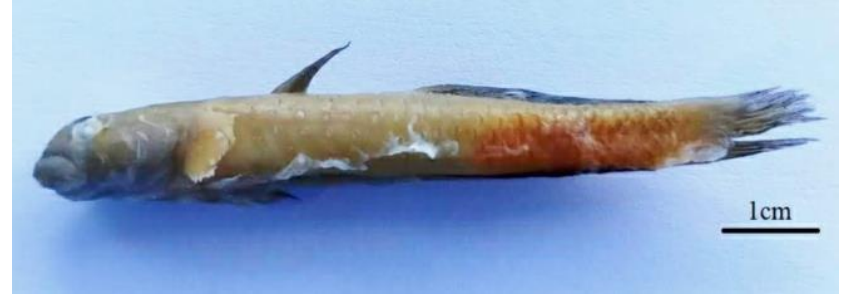

Figure 2. Fixed specimen of male Sicyopus auxilimentus (GBI0044) found in Laine river in Sangihe Island, North Sulawesi, Indonesia

$\begin{array}{ll}\text { Scientific classification } \\ \text { Kingdom } & \text { : Animalia } \\ \text { Phylum } & \text { : Chordata } \\ \text { Class } & \text { : Actinopterygii } \\ \text { Order } & \text { : Gobiioformes } \\ \text { Family } & \text { : Gobiidae } \\ \text { Subfamily } & \text { : Sicydiinae } \\ \text { Genus } & \text { : Sicyopus } \\ \text { Species } & \text { : Sicyopus auxilimentus (Watson and } \\ & \text { Kottelat 1994) (Figure 2) } \\ \text { Local name } & \text { : Ikan Gobi }\end{array}$

\section{Meristic and morphological characters of Sicyopus auxilimentus collected from Sangihe Island}

Meristic characters of $S$. auxilimentus are given in Table 1. Other specific morphological characters of male $S$. auxilimentus are as follows: the base of the first dorsal fin was not connected to the base second dorsal fin; the distance between the base of first dorsal fin and second dorsal fin was generally less than half of the eye diameter; ventral fin rays were fused to belly between fifth rays only; caudal fin rays posterior margin were rounded; scales were all ctenoid; scales presented on caudal peduncle and between anal and second dorsal fins; while anterior to this, scales became widely spaced and did not imbricate. Coloration in preserved specimen was as follows: background yellowish; scales edge in brown; posterior part of flanks and caudal peduncle orange; first dorsal fin black, second dorsal fin dusky black; pectoral fin slightly brown; ventral fin slightly dusky; anal fin blackish; and, caudal fin dusky brown.

Table 1. Meristic of male Sicyopus auxilimentus collected from the Laine river in Sangihe Island, North Sulawesi, Indonesia $(n=$ 1 specimen)

\begin{tabular}{lcc}
\hline \multicolumn{1}{c}{ Meristics (counts) } & $\begin{array}{c}\text { Present } \\
\text { study }\end{array}$ & $\begin{array}{c}\text { Keith et al. } \\
\text { (2015) }\end{array}$ \\
\hline First dorsal fin rays & VI & VI \\
Second dorsal fin rays & $\mathrm{I}+9$ & $\mathrm{I}+9$ \\
Ventral fin rays & $\mathrm{I}+5$ & $\mathrm{I}+5$ \\
Pectoral fin rays & 14 & $14-15$ \\
Anal fin rays & $\mathrm{I}+9$ & $\mathrm{I}+9$ \\
Caudal fin rays & 13 & 13 \\
Scales in lateral series & 19 & $18-23$ \\
Scales in zigzag series & 7 & $6-11$ \\
Scales in transverse series backward & 7 & $4-12$ \\
Scales in transerves series forward & 4 & $2-7$ \\
\hline
\end{tabular}




\section{Contemporary records and their habitat}

The discovery of $S$. auxilimentus in the Sangihe island is a new record of this species in addition to its previous records. Several studies on freshwater goby in Indonesian waters have sometimes been limited to a single island. As is the case for S. auxilimentus records in Indonesian waters, Watson and Kottelat (1994) have recorded S. auxilimentus in Halmahera, then Keith et al. (2015) recorded $S$. auxilimentus in East Java, Bali, and Lombok (Figure 3). Among other biological topics, new records of vulnerable fish contribute to understanding species diversity and biogeography (Hasan et al. 2019a,b; Saptadjaja et al. 2020; Ihwan et al. 2020). As reported in this paper, the new record of S. auxilimentus has improved knowledge of the species, as it extends recorded distribution range of the species (Thuesen et al. 2011; Maeda and Palla 2015).

The presence of $S$. auxilimentus in Sangihe Island indicates that the freshwater ecosystems in Sangihe island are in a good state. Compared to Western Indonesia, inland waters in Sangihe island are protected from heavy pollution, and this island has many clear streams. In the future, data collection, i.e., assisted by local fishermen is needed to assess the occurrence of S. auxilimentus and to evaluate the importance of small islands in Sulawesi waters as part of the migration route, nursery ground, and growth ground of this species.

The life history of $S$. auxilimentus is strongly dependent on freshwater. This species has the osmoregulatory plasticity to acclimate to the marine environment and prefers low salinity of inland river waters. A reason for this may be to avoid predators, and to take advantage of prey abundance in lower-salinity areas, rather than because of a physiological constraint. This species spawns in freshwaters, with the embryos drifting downstream to the sea were to undergo a planktonic phase, before returning to the rivers to grow and reproduce, and hence are referred to as amphidromous (McDowall 2007; McDowall 2009a). Details of their biological cycle and the parameters leading to such extreme evolution in amphidromous gobies are poorly known (Lord and Keith 2007; McDowall 2009b), despite the fact that these gobies contribute most to the diversity of fish communities in the Indo-Pacific, have the highest levels of endemism (Nelson et al. 1997; Keith and Lord 2011).

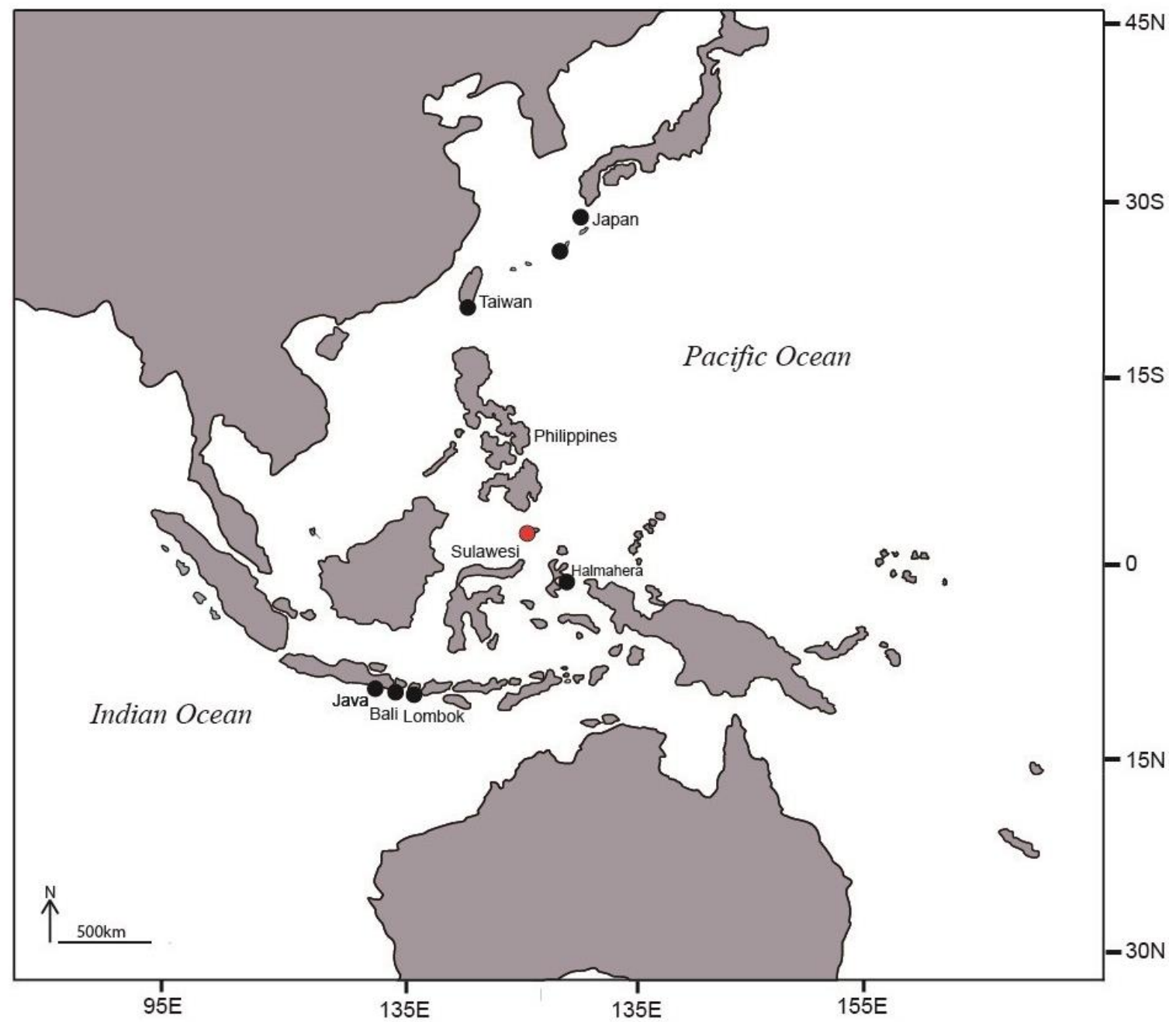

Figure 3. Distribution of S. auxilimentus in Indo-Pacific regions. Black circles are the previous record. Red circle is the recent record from Sangihe Island, North Sulawesi, Indonesia 
Environmental factors influencing the movement of $S$. auxilimentus have received little attention, even though the study of these factors is important to help predict how these gobies will respond to increasing modifications of aquatic systems (Jenkins et al. 2009; Ebner and Thuesen 2011; Ebner et al. 2011). Several environmental factors may interact to influence Sicydiinae movement patterns, including water temperature, dissolved oxygen, and salinity. Water quality parameters may also play an indirect role in $S$. auxilimentus movement due to the influence of fluctuating conditions on the distribution of prey species. Water conditions of Laine waterfall, Sangihe island, such as salinity $3.5 \mathrm{psu}$, temperature $23-25^{\circ} \mathrm{C}$, and dissolved oxygen 7.7-9.2 mg/l, were ideal for $S$. auxilimentus habitat (Bell and Brown 1995; Ellien et al. 2011; Keith et al. 2011a; Watanabe et al. 2014; Muthiadin et al. 2020). Future research, incorporating long-term trends with these short-term results, would help form a more complete understanding of the degree to which environmental parameters influence movement of the species. The role of temperature and salinity in presence of $S$. auxilimentus, when observed over a longer period, will reveal the part played by seasonal variation.

\section{Utilization of Sicyopus auxilimentus}

$S$. auxilimentus is not the main commodity of fisheries capture on Sangihe Island because their numbers are very low. Several other fish were caught during the sampling apart from $S$. auxilimentus, including Tank goby Glossogobius giuris, Throat-spine gudgeon Belobranchus belobranchus, Golden tank goby Glossogobius aureus, Scribbled goby Awaous grammepomus, Broadhead sleeper Eleotris melanosome, Sharptail goby Oligolepis acutipennis, Milkfish Chanos chanos, Sleepy goby Psammogobius biocellatus, Puntang goby Exyrias puntang, Barramundi Lates calcalifer, Northern mud gudgeon Ophiocara porocephala, Eyebrow goby Oxyurichthys ophthalmonema, Hasselt's goby Callogobius hasseltii, Jungle perch Kuhlia rupestris, Dark-margined flagtail Kuhlia marginata, Flathead grey mullet Mugil cephalus, Bearded roguefish Tetraroge barbata, Long tongue sole Cynoglossus lingua, Buffon's river-garfish Zenarchopterus buffonis, Snakehead gudgeon Giuris margaritacea, Dusky sleeper Eleotris fusca, and Nile tilapia Oreochromis niloticus. All the brackish and freshwater fishes caught were native fish of Indonesia, except for O. niloticus (Hasan et al. 2019c; Insani et al. 2020). There is no official record of how many $S$. auxilimentus are caught because they are not a targeted species for Indonesia commercial fisheries, even though $S$. auxilimentus is in great demand as an ornamental fish, i.e., by hobbyists from abroad (Delventhal 2003; Maeda et al. 2011; Mukai 2011; Hubert et al. 2015). Unique body shape and striking color patterns can make this species quite expensive. The Indonesian government needs to strictly prohibit the practice of catching Sicydiinae goby, especially S. Auxilimentus, Such that if the fish are caught as part of commercial catch, they can immediately release again, so that the population of $S$. auxilimentus remains stable in Indonesian waters.
The collection of only one male individual of $S$. auxilimentus in a timeframe of four days of sampling at Laine river, Sangihe island during our study, suggests that this species, like its subfamily, is rare. In addition, there is worry that the location where this species is found is very close to tourist areas. Cooperation among the government, researchers, and local people is needed to protect the waters in Sangihe island so that the $S$. auxilimentus population remains stable.

\section{Conservation status}

The range of $S$. auxilimentus can determine the species' potential interaction with fisheries and its vulnerability to human intervention. Because it lives in inshore, estuarine, and freshwater regions, close to human settlements, it is vulnerable to human activity. $S$. auxilimentus is not currently legally protected in any part of its distribution area. Further research is necessary to better characterize its ecological, biological, and fishery significance (Kottelat 1996; Keith 2003b; Palidoro et al. 2010; Walter et al. 2012).

Sicyopus auxilimentus is categorized as Vulnerable (VU) by the IUCN because their habitats are located near human settlements (Kottelat 1996). The consequences of human actions to freshwater and marine ecosystems have become apparent with the profound, recent global declines of fish population, including $S$. auxilimentus. However, despite their ecological significance, populations of many species of Sicydiinae are declining on a global scale, mainly due to unsustainable and illegal fishing practices (Devick et al. 1995; Keith 2003a; Walter et al. 2013). In addition, the entry of invasive species can cause the loss of local fish populations in Indonesia (Hasan et al. 2019c; Hasan et al. 2020a; Hasan et al. 2020b; Hasan et al. 2020d; Serdiati et al. 2020).

Freshwater gobies such as $S$. auxilimentus are potentially highly vulnerable to urban habitat modification. Freshwater habitats have more limited volume, a disadvantage in resisting changes in physicochemical properties (Ceccarelli et al. 2013; Potter et al. 2015). Because of their association with freshwaters, coastal, and estuarine environments, S. auxilimentus are also susceptible to both the habitat degradation and influence of climate change (Bell 2007; Pankhurst and Munday 2011; Chabarria and Pezold 2013). In the future, more complete data collection is needed to assess the occurrence of $S$. auxilimentus and to evaluate the importance of Sangihe waters as breeding areas, growth ground, and migration routes (Yamasaki and Tachihara 2006; Keith et al. 2011a; Walter et al. 2012).

\section{DNA barcode and species confirm}

DNA-barcoding of freshwater goby from Sangihe island was successfully sequenced with a base-pair length of 672 bp (Table 2). According to Ward et al. (2005), a total of 207 DNA barcoding fish species in Australia is identified using Fish_F1 and Fish_R1 primers obtain 655 bp of COI gene. Fragments that have more than 658 base pairs of COI genes can be used as a standard to distinguish 


\section{Domestication efforts}

S. auxilimentus has an important economic value, especially for aquarium trade (Mukai 2011; Maeda and Tan 2013). They are rare in several regions in the Indo-Pacific island and are mostly wild catch, whether as juveniles or adults, without any aquaculture program. A comprehensive study of the biology of the fish is necessary before carrying out a domestication program (Hasan et al. 2019d; Widodo et al. 2020: Valen et al. 2020). Mapping potential on natural distribution is one of the necessary strategies (Hasan et al. 2019b; Hasan and Islam 2020), and aspects of the environment, reproduction, and food availability must be taken into account (Herawati et al. 2016; Hasan et al. 2020c; Saptadjaja et al. 2020). Until now, the study of $S$. auxilimentus remains very limited, so opportunities to study it are open to support $S$. auxilimentus domestication effort.

\section{ACKNOWLEDGEMENTS}

We thank the reviewers and editor for their insightful comments, Zoology Division, Generasi Biologi Indonesia Foundation, local fisherman, Asief Abdi, Muhammad Badrut Tamam, and Fuazi as our guide, and Lembaga Pengelola Dana Pendidikan (LPDP) for funding our research (no. 20160221035555).

\section{REFERENCES}

Ardura A, Linde, AR, Moreira, JC, Garcia-Vazquez E. 2010. DNA barcoding for conservation and management of Amazonian commercial fish. Biol Cons 143 (6): 1438-1443.

Bell KNI. 2007. Opportunities in stream drift: Methods, goby larval types, temporal cycles, in situ mortality estimation, and conservation implications. Bishop Mus Bull Cultural Environ Stud 3: 35-61.

Bell KNI, Brown JA. 1995. Active salinity choice and enhanced swimming endurance in 0-to 8-d-old larvae of diadromous gobies, including Sicydium punctatum (Pisces), in Dominica, West Indies. Mar Biol 121: 409-417.

Boseto DT, Magnuson SJF, Pezold FL. 2016. Population genetic structure of the goby Stiphodon rutilaureus (Gobiidae) in the New Georgia Group, Solomon Islands. Pac Conserv Biol 22 (3): 281-291. DOI: 10.1071/PC14934.

Ceccarelli DM, Frisch AJ, Graham NAJ, Ayling AM, Beger M. 2013 Habitat partitioning and vulnerability of sharks in the Great Barrier Reef Marine Park. Rev Fish Biol Fish 24 (1): 169-197. DOI 10.1007/s11160-013-9324-8.

Chabarria R, Pezold F. 2013. Phylogeography and historical demography of Sicydium salvini in the eastern Pacific. Ichthyol Res 60: 353-362.

Chen IS, Shao KT. 1998. A new species of goby, Sicyopus cebuensis (Teleostei: Gobiidae) from Cebu Island, Philippines. Acta Zoologica Taiwanica 9 (2): 97-103.

Christoffersen M, Svendsen JC, Behrens JW, Jepsen N, van Deurs M. 2019. Using acoustic telemetry and snorkel surveys to study diel activity and seasonal migration of round goby (Neogobius melanostomus) in an estuary of the Western Baltic Sea. Fish Manag Ecol 26 (2): 172-182. DOI: 10.1111/fme.12336.

Cloern JE. 2018. Why large cells dominate estuarine phytoplankton. Limnol Oceanogr 63: 392-409. DOI: 10.1002/lno.10749.

Dahruddin H, Hutama A, Busson F, Sauri S, Hanner R, Keith P, Hadiaty RK, Hubert N. 2017. Revisiting the ichthyodiversity of Java and Bali through DNA barcodes: Taxonomic coverage, identification accuracy, cryptic diversity and identification of exotic species. Mol Ecol Resour 17 (2): 288-299. DOI: 10.1111/1755-0998.12528.
Delventhal N. 2003. Goby queries. J Intl Goby Soc 3 (1): 4-8. DOI: 10.1111/j.1095-8312.2008.01135.x.

Devick WS, Fitzsimons JM, Nishimoto RT. 1995. Threatened fishes of the world: Lentipes concolor Gill, 1860 (Gobiidae). Environ Biol Fish 44: 325-326.

Ebner BC, Thuesen PA, Larson HK, Keith P. 2011. A review of distribution, field observations and precautionary conservation requirements for Sicydiine gobies in Australia. Cybium 35 (4): $397-$ 414.

Ebner BC, Thuesen P. 2011. Discovery of stream-cling-goby assemblages (Stiphodon species) in the Australian wet tropics. Aust J Zool 58 (6): 331-340. DOI: 10.1071/ZO10061.

Ellien C, Werner U, Keith P. 2014. Morphological changes during the transition from freshwater to seawater in an amphidromous goby, Sicyopterus lagocephalus (Pallas 1770) (Teleostei). Ecol Freshw Fish 25 (1): 48-59. DOI: 10.1111/eff.12190.

Ellien C, Valade P, Bosmans J, Taillebois L, Teichert N, Keith P. 2011. Influence of salinity on larval development of Sicyopterus lagocephalus (Pallas, 1770) (Gobioidei). Cybium 35: 381-390.

Felsenstein J. 1985. Confidence limits on phylogenies: an approach using the bootstrap. Evol 39: 783-791. DOI: 10.1111/j.15585646.1985.tb00420.x

Gill AC, Mooi RD. 2012. Thalasseleotrididae, new family of marine gobioid fishes from New Zealand and temperate Australia, with a revised definition of its sister taxon, the Gobiidae (Teleostei: Acanthomorpha). Zootaxa 3266: 41-52. DOI: 10.5281/zenodo. 208398 .

Harrison IJ. 1989. Specialization of the gobioid palatopterygoquadrate complex and its relevance to gobioid systematics. J Nat Hist 23: 325353. DOI:10.1080/00222938900770211.

Hasan V, Soemarno, Widodo MS, Wiadnya DGR, Mukti AT, Irawan B. 2019a. Distribution extension and first record of Lobocheilos falcifer (Cypriniformes, Cyprinidae) in Central Java Province, Indonesia. Ecol Environ Conserv 25: S158-S161.

Hasan V, Soemarno, Widodo MS, Wiadnya DGR. 2019b. Lobocheilos falcifer (Valenciennes, 1842) (Cypriniformes, Cyprinidae): distribution extension in Java and first record from Tuntang river, Semarang Regency, Indonesia. Ecol Environ Conserv 25 (4): 17131715 .

Hasan V, Pratama F, Malonga WAM, Cahyanurani AB. 2019c. First record of the Mozambique Tilapia Oreochromis mossambicus Peters, 1852 (Perciformes: Cichlidae) on Kangean Island, Indonesia. Neotrop Biol Conserv 14 (2): 207-211. DOI : 10.3897/neotropical.14.e35601.

Hasan V, Mukti AT, Putranto TWC. 2019d. Range expansion of the invasive nile tilapia Oreochromis niloticus (Perciformes: Cichlidae) in Java Sea and first record for Kangean Island, Madura, East Java, Indonesia. Ecol Environ Conserv 25: S187-S189.

Hasan V, Tamam MB. 2019. First record of the invasive Nile Tilapia, Oreochromis niloticus (Linnaeus, 1758) (Perciformes, Cichlidae), on Bawean Island, Indonesia. Check List 15 (1): 225-227. DOI: 10.15560/15.1.225.

Hasan V, Widodo MS. 2020. Short Communication: The presence of bull shark Carcharhinus leucas (Elasmobranchii: Carcharhinidae) in the fresh waters of Sumatra, Indonesia. Biodiversitas 21 (9): 4433-4439. DOI: 10.13057/biodiv/d210962.

Hasan V, Widodo MS, Islamy RA, Pebriani DAA. 2020a. New records of alligator gar, Atractosteus spatula (Actinopterygii: Lepisosteiformes: Lepisosteidae) from Bali and Java, Indonesia. Acta Ichthyologica et Piscatoria 50 (2): 233-236.

Hasan V, Widodo MS, Faqih AR, Mahasri G, Arief M, Valen FS, Tamam MB, Yonarta D, Pratama FS, Fitriadi R. 2020b. Presence of striped flying barb Esomus metallicus (Teleostei, Cyprinidae) from West Sumatra, Indonesia. Ecol Environ Conserv 26: S73-S75.

Hasan V, Soemarno, Widodo MS, Wiadnya DGR. 2020c. New distributional record of the Beardless barb Cyclocheilichthys apogon (Valenciennes, 1842) (Cypriniformes: Cyprinidae) from Madura Island, Indonesia. BIOTROPIA 1-7. DOI: 10.11598/btb.0.0.0.1276

Hasan V, Faqih AR, Maftuch. 2020d. Range expansion of Parachromis managuensis (Günther, 1867) (Perciformes, Cichlidae) in Java, Indonesia. BIOTROPIA 1-7. DOI: 10.11598/btb.0.0.0.1278

Hasan V, Islam I. 2020. First inland record of bull shark Carcharhinus leucas (Müller \& Henle, 1839) (Carcharhiniformes: Carcharhinidae) in Celebes, Indonesia. Ecologica Montenegrina 38: 12-17. DOI: 10.37828/em.2020.38.3. 
Hebert PDN, Cywinska A, Ball SL, de Waard JR. 2003. Biological identifications through DNA barcodes. Proc Royal Soc Lond 270 313-321. DOI: 10.1098/rspb.2002.2218.

Herawati TA, Yustiatia A, Nurhayatia, Natadia SS. 2016. Domestication of marble goby [Oxyeleotris marmorata (Bleeker, 1852)] Indigenous fish of Citarum river, Indonesia. Aquat Proc 7: 247-253.

Hoareau TB, Boissin E, Berrebi P. 2012. Evolutionary history of a widespread Indo-Pacific goby: The role of Pleistocene sea-level changes on demographic contraction/expansion dynamics. Mol Phylogen Evol 62 (1): 566-572. DOI: 10.1016/j.ympev.2011.10.004.

Hubert N, Kadarusman, Wibowo A, Busson F, Caruso D, Sulandari S, Nafiqoh N, Pouyaud L, Rüber L, Avarre J, Herder F, Hanner R, Keith P, Hadiaty RK. 2015. DNA Barcoding Indonesian freshwater fishes: Challenges and prospects. De Gruyter Open 3: 144-169. DOI: 10.1515/dna-2015-0018.

Ihwan, Pratama FS, Yonarta D, Faqih AR, Widodo MS, Valen FS, Tamam MB, Hasan V. 2020. Presence of Asian catfish Claria batrachus (Siluriformes, Clariidae) in Madura Island, Indonesia. AACL Bioflux 13 (2): 958-962.

Iida M, Watanabe S, Tsukamoto K. 2015. Oceanic larval duration and recruitment mechanism of the amphidromous fish Sicyopterus japonicus (Gobioidei: Sicydiinae). Reg Stud Mar Sci 1: 25-33. DOI: 10.1016/j.rsma.2015.03.001

Imtiaz A, Mohd Nor SA, Md. Naim D. 2017. Review: Progress and potential of DNA barcoding for species identification of fish species. Biodiversitas 18 (4): 1394-1405. DOI: 10.13057/biodiv/d180415.

Insani L, Hasan V, Valen FS, Pratama FS, Widodo MS, Faqih AR, Islamy RA, Mukti AT, Isroni W. 2020. Presence of the invasive nile tilapia Oreochromis niloticus Linnaeus, 1758 (Perciformes, Cichlidae) in the Yamdena Island, Indonesia. Ecol Environ Conserv 26 (3): 1115-1118.

Islamy RA, Hasan V. 2020. Checklist of mangrove snails (Mollusca: Gastropoda) in South coast of Pamekasan, Madura Island, East Java Indonesia. Biodiversitas 21 (7): 3127-3134. DOI $10.13057 /$ biodiv/d210733

Ivanova NV, Zemlak TS, Hanner RH, Hebert PDN. 2007. Universal primer cocktails for fish DNA barcoding. Mol Ecol Notes7: 544-548.

Jenkins AP, Jupiter SD, Quanqau I, Atherton J. 2009. The importance of ecosystem-based management for conserving aquatic migratory pathways on tropical high islands: a case study from Fiji. Aquat Conserv 20: 224-238. DOI: 10.1002/aqc.1086.

Keith P. 2003a. Biology and ecology of amphidromous Gobiidae of the Indo-Pacific and the Caribbean regions. J Fish Biol 63: 831-847. DOI: 10.1046/j.1095-8649.2003.00197.x

Keith P. 2003b. Review paper: Biology and ecology of amphidromous Gobiidae of the Indo-Pacific and the Caribbean regions. J Fish Biol 63: 831-847. DOI: 10.1046/j.1095-8649.2003.00197.x.

Keith P, Hadiaty R, Busson F, Hubert N. 2014a. A new species of Sicyopus (Teleostei: Gobioidei) from Indonesia. Cybium 38 (3): 173178. DOI: $10.26028 /$ cybium/2019-423-004.

Keith P, Hadiaty R, Busson F, Hubert N. 2014b. A new species of Sicyopus (Gobiidae) from Java and Bali. Cybium 38 (3): 173-178. DOI: $10.26028 /$ cybium/2014-383-002.

Keith P, Lord C. 2011a. Tropical freshwater gobies: Amphidromy as a life cycle. In: Patzner RA, Van Tassell JL, Kovacic M, Kapoor BG (eds). The Biology of Gobies. Science Publishers Inc, New York.

Keith P, Lord C, Lorion J, Watanabe S, Tsukamoto K, Cruaud C, Couloux A, Dettai A. 2011b. Phylogeny and biogeography of Sicydiinae (Teleostei: Gobioidei) inferred from mitochondrial and nuclear genes. Mar Biol 158 (2): 311-326. DOI: 10.1007/s00227-010-1560-Z.

Keith P, Lord C, Maeda K. 2015. Indo-Pacific Sicydiine GobiesBiodiversity, Life Traits and Conservation. Société Francaise d'Ichtyologie, Paris.

Keith P, Marquet G, Pouilly M. 2009. Stiphodon mele n. sp., a new species of freshwater goby from Vanuatu and New Caledonia (Teleostei, Gobiidae, Sicydiinae), and comments about amphidromy and regional dispersion. Zoosyst 31 (3): 471-483. DOI: $10.5252 / \mathrm{z} 2009 \mathrm{n} 3 \mathrm{a} 5$

Keith P, Marquet G, Taillebois L. 2011b. Discovery of the freshwater genus Sicyopus (Teleostei: Gobioidei: Sicydiinae) in Madagascar, with a description of a new species and comments about regional dispersal. J Nat Hist 45 (43-44): 2725-2746. DOI: 10.1080/00222933.2011.602479.

Keith P, Hadiaty RK. 2014. Stiphodon annieae, a new species of freshwater goby from Indonesia (Gobiidae). Cybium 38 (4): 267-272.

Keith P, Lord C, Vigneux E. 2006. In vivo observations on postlarval development of freshwater gobies and eleotrids from French
Polynesia and New Caledonia. Ichthyol Explor Freshw 17 (2): 187191.

Keith P, Allen G, Lord C, Hadiaty RK. 2011b. Five new species of Sicyopterus (Gobioidei: Sicydiinae) from Papua New Guinea and Papua. Cybium 35 (4): 299-318.

Keith P, Galewski T, Cattaneo-Berrebi G, Hoareau T, Berrebi P. 2005. Ubiquity of Sicyopterus lagocephalus (Teleostei: Gobioidei) and phylogeography of the genus Sicyopterus in the Indo-Pacific area inferred from mitochondrial cytochrome b gene. Mol Phylogen Evol 37: 721-732. DOI:10.1016/j.ympev.2005.07.023

Keith P, Hadiaty RK, Hubert N, Busson F, Lord C. 2014. Three new species of Lentipes from Indonesia (Gobiidae). Cybium 38 (2): 133146.

Kolding J, van Zwieten P. 2014. Sustainable fishing of inland waters. J Limnol 73 (s1): 132-148. DOI: 10.4081/jlimnol.2014.818.

Kottelat M. 1996. Sicyopus auxilimentus. The IUCN Red List of Threatened Species 1996: e.T20201A9178252. DOI: 10.2305/IUCN.UK.1996.RLTS.T20201A9178252.en.

Lakra WS, Verma MS, Goswami M, Lal KK, Mohindra V, Punia P, Gopalakrishnan A, Singh KV, Ward RD, Hebert P. 2011. DNA barcoding Indian marine fishes. Mol Ecol Res 11 (1): 60-71.

Lin CC. 2007. A Field Guide to Freshwater Fish and Shrimps in Taiwan. Commonwealth Publishing, Taiwan.

Lord C, Keith P. 2007. Threatened fishes of the world: Sicyopterus sarazini Weber \& De Beaufort (Gobiidae). Environ Biol Fish 83 (2): 169-170. DOI: $10.1007 / \mathrm{s} 10641-007-9311-9$

Lord C, Brun C, Hautecoeur M, Keith P. 2010. Comparison of the duration of the marine larval phase estimated by otolith microstructural analysis of three amphidromous Sicyopterus species (Gobiidae: Sicydiinae) from Vanuatu and New Caledonia: Insights on endemism. Ecol Freshw Fish 19: 26-38. DOI: 10.1007/s10641-0079311-9

Maeda K, Palla HP. 2015. A new species of the genus Stiphodon from Palawan, Philippines (Gobiidae: Sicydiinae). Zootaxa 4018 (3): 381395. DOI: 10.11646/zootaxa.4018.3.3

Maeda K, Mukai T, Tachihara K. 2011. A new species of Amphidromous goby, Stiphodon alcedo, from the Ryukyu archipelago (Gobiidae: Sicydiinae). Cybium 35 (4): 285-298.

Maeda K, Tan HH. 2013. Review of Stiphodon (Gobiidae: Sicydiinae) from Western Sumatra, with description of a new species. Raffles Bull Zool 61 (2): 749-761.

McDowall RM. 2009a. Early hatch: A strategy for safe downstream larval transport in Amphidromous gobies. Rev Fish Biol Fish 19 (1): 1-8. DOI: $10.1007 / \mathrm{s} 11160-008-9085-\mathrm{y}$

McDowall RM. 2009b. Why be Amphidromous: Expatrial dispersal and the place of source and sink population dynamics? Rev Fish Biol Fish 20 (1): 87-100. DOI: 10.1007/s11160-009-9125-2.

McDowall RM. 2007. On amphidromy, a distinct form of diadromy in aquatic organisms. Fish Fish 8 (1): 1-13. DOI: 10.1111/j.14672979.2007.00232.x

Md-Zain BM, Abdul-Mutalib SA, Aifat NR, Masstor NH, Mohd-Yusof NS, Mohd-Hashim A, Abdul-Latiff MAB, Yaakop S, Samat A. 2018a. Molecular phylogenetic inference of White-Spotted Guitarfish (Rhynchobatus australiae) collected from local Malaysian fish markets. Biodiversitas 19 (4): 1382-1386. DOI: 10.13057/biodiv/d190426.

Md-Zain BM, Abid-Kamal SNA, Aifat NR, Abdul-Latiff MAB, MohdHashim A, Ampeng A, Yaakop S, Samat A. 2018b. Molecular identification of shark fins in Malaysian Borneo's local markets. Biodiversitas 19 (3): 1035-1043. DOI: 10.13057/biodiv/d190336.

Metcalfe JD, Craig JF. 2011. Ethical justification for the use and treatment of fishes in research: An update. J Fish Biol 78 (2): 393-394. DOI: 10.1111/j.1095-8649.2010.02900.x

Mukai T. 2011. How to keep tropical freshwater gobies in your home aquarium. Aqualife 33 (2): 74-79.

Murdy E. 2011a. The systematics of Amblyopinae, In: Patzner RA, Van Tassell JL, Kovacic M, Kapoor B (eds). The Biology of Gobies. Science Publishers, Enfield, New Hampshire.

Murdy E. 2011b. Systematics of Oxudercinae, In: Patzner RA, Van Tassel JL, Kovacic M, Kapoor B (eds). The Biology of Gobies. Science Publishers, Enfield, New Hampshire.

Muthiadin C, Aziz IR, Hasyimuddin, Nur F, Sijid SA, Azman S, Hadiaty RK, Alimuddin I. 2020. Penja fish (Genus: Sicyopterus) from Karama river, West Sulawesi, Indonesia: Growth pattern and habitat characteristics. Biodiversitas 21 (10): 4959-4966. DOI: 10.13057/biodiv/d211062. 
Nei M, Kumar S. 2000. Molecular Evolution and Phylogenetics. Oxford University Press, New York.

Nelson SG, Parham JE, Tibatts RB, Camacho FA, Leberer T, Smith BD. 1997. Distribution and microhabitats of the amphidromous gobies in streams of Micronesia. Micronesica 30: 83-91.

Nuryanto A, Komalawati N, Sugiharto. 2019. Genetic diversity assessment of Hemibagrus nemurus from rivers in Java Island, Indonesia using COI gene. Biodiversitas 20 (9): 2707-2717. DOI: 10.13057/biodiv/d200936.

Padial JM, Miralles A, de la Riva I, Vences M. 2010. The integrative future of taxonomy. Front Zool 7: 16. DOI: 10.1186/1742-9994-7-16

Potter IC, Warwick RM, Hall NG, et al. 2015. The physicochemical characteristics, biota and fisheries of estuaries. Freshw Fish Ecol 48 79. DOI: $10.1002 / 9781118394380 . \operatorname{ch} 5$

Pankhurst NW, Munday PL. 2011. Effects of climate change on fish reproduction and early life-history stages. Mar Freshw Res 62 (9): 1015-1026. DOI: 10.1071/MF10269.

Parenti LR, Maciolek JA. 1993. New Sicydiine gobies from Ponape and Palau, Micronesia, with comments on systematics of the subfamily Sicydiinae (Teleostei: Gobiidae). Bull Mar Sci 53 (3): 945-972.

Patzner RA. 2011. The Biology of Gobies. 1st ed. Science Publishers, Enfield, New Hampshire.

Pezold F. 2011. Systematics of the Family Gobionellidae. In: Patzner RA Vantassel JL, Kovacic M, Kapoor B (eds.). The Biology of Gobies. Science Publishers, Enfield, New Hampshire.

Ratnasingham S, Hebert PD. 2007. BOLD: The barcode of life data system (www.barcodinglife.org). Mol Ecol Notes 7: 355-364. DOI: 10.1111/j.1471-8286.2007.01678.x

Roesma DI, Tjong DH, Karlina W, Aidil DR. 2019. Taxonomy confirmation of Puntius cf. binotatus from Gunung Tujuh Lake based on Cytochrome Oxidase-I (COI) gene. Biodiversitas 20 (1): 54-60. DOI: $10.13057 /$ biodiv/d200107.

Saitou N, Nei M. 1987. The neighbor-joining method: A new method for reconstructing phylogenetic trees. Mol Biol Evol 4: 406-425. DOI: 10.1093/oxfordjournals.molbev.a040454.

Saptadjaja AM, Hasan V, Arief M, Isroni W, Rozi. 2020. First record of threatened Asian Catfish, Clarias batrachus (Linnaeus, 1758 (Siluriformes, Clariidae) from Kangean Island, Indonesia. Ecol Environ Conserv 26 (3): 1055-1058.

Serdiati N, Yonarta D, Pratama FS, Faqih AR, Valen FS, Tamam MB, Hamzah YIG, Hasan V. 2020 Andinoacara rivulatus (Perciformes: Cichlidae), an introduced exotic fish in the upstream of Brantas River, Indonesia. AACL Bioflux 13 (1): 137-141.

Sutarno, Budiharjo A, Setyawan AD, Lymbery AJ. 2017. Sequence variation among populations of sawfishes (Pristiformes: Pristidae) from Indonesia and Australia. Biodiversitas 18: 850-856. DOI 10.13057/biodiv/d180259.

Suzuki T, Senou H, Yano K, Yonezawa T, Oseko N. 2009. First records of four gobiid fish from the Ryukyu Islands, Japan. Bull Osaka Mus Nat Hist 63: 1-10.

Taillebois L, Maeda K, Vigne S, Keith P. 2012. Pelagic larval duration of three amphidromous Sicydiinae gobies (Teleostei: Gobioidei) including widespread and endemic species. Ecol Freshw Fish 21 (4): 552-559. DOI: 10.1111/j.1600-0633.2012.00575.x.

Taillebois L, Castelin M, Lord C, Chabarria R, Dettai A, Keith P. 2014 New Sicydiinae phylogeny (Teleostei: Gobioidei) inferred from mitochondrial and nuclear genes: Insights on systematics and ancestral areas. Mol Phylogen Evol 70: 260-271. DOI: 10.1016/j.ympev.2013.09.026.

Taillebois L, Castelin M, Ovenden JR, Bonillo C, Keith P. 2013 Contrasting genetic structure among populations of two amphidromous fish species (Sicydiinae) in the Central West Pacific. PLoS ONE 8: 1-13. DOI: 10.1371/journal.pone.0075465.

Tamura K, Stecher G, Peterson D, Filipski A, Kumar S. 2013. MEGA6: Molecular evolutionary genetics analysis version 6.0. Mol Biol Evol 30: 2725-2729. DOI: 10.1093\%2Fmolbev\%2Fmst197.

Teichert N, Keith P, Valade P, Richarson M, Metzger M, Gaudin P. 2013. Breeding pattern and nest guarding in Sicyopterus lagocephalus, a widespread amphidromous Gobiidae. J Ethol 31: 239-247.

Thacker CE. 2011. Systematics of Gobiidae. In: Patzner RA, Vantassel JL, Kovacic M, Kapoor B (eds.). The Biology of Gobies. Science Publishers, Enfield, NH, USA.

Thacker CE, Roje DM. 2011. Phylogeny of Gobiidae and identification of gobiid lineages. Syst Biodivers 9: 329-347. DOI: 10.1080/14772000.2011.629011.

Thuesen PA, Ebner BC, Larson H, Keith P, Silcock RM, Prince J, Russell DJ. 2011. Amphidromy links a newly documented fish community of continental Australian streams, to oceanic islands of the West Pacific. PloS ONE 6: e26685. DOI: 10.1371/journal.pone.0026685.

Tornabene L, Chen Y, Pezold F. 2013. Gobies are deeply divided: Phylogeneticevidence from nuclear DNA (Teleostei: Gobioidei: Gobiidae). Syst Biodivers 11 (3): 345-61. DOI: 10.1080/14772000.2013.818589.

Valen FS, Soemarno, Widodo MS, Wiadnya DGR. 2020. Contemporary distribution records of yellow finned Barb Mystacoleucus marginatus (Valenciennes, 1842) in Brantas Basin, Indonesia. Ecol Environ Conserv 26: S40-S43.

Wall AJ. 2001. Ethical considerations in the handling and slaughter of farmed fish. In: Kestin SC, Warriss PD (eds.). Farmed Fish Quality. Fishing News Books, Oxford, UK.

Walter RP, Hogan JD, Blum MJ, Gagne RB, Hain EF, Gilliam JF, McIntyre PB. 2012. Climate change and conservation of endemic amphidromous fishes in Hawaiian streams. Endanger Species Res 16: 261-272. DOI: 10.3354/esr00404.

Ward RD, Zemlak TS, Innes BH, Last P, Hebert PDN. 2005 DNA barcoding Australia's fish species. Philosophical Transactions of the Royal Society B 360: 1847-1857. DOI: 10.1098\%2Frstb.2005.1716.

Watanabe S, Iida M, Lord C, Keith P, Tsukamoto K. 2014. Tropical and temperate freshwater amphidromy: A comparison between lifehistory characteristics of Sicydiinae, ayu, sculpins and galaxiids. Rev Fish Biol Fisheries 24: 1-14. DOI: 10.1007/s11160-013-9316-8.

Watson RE, Keith P, Marquet G. 2007. Akihito Vanuatu, a new genus and new species of freshwater goby from the South Pacific (Teleostei: Gobioidei: Sicydiinae). Cybium 31 (3): 341-349.

Watson RE, Kottelat M. 2006. Two new freshwater gobies from Halmahera, Maluku, Indonesia (Teleostei: Gobioidei: Sicydiinae). Ichthyol Explor Freshw 17 (2): 121-128.

Watson RE. 1995. Gobies of the genus Stiphodon from French Polynesia, with descriptions of two new species (Teleostei: Gobiidae: Sicydiinae). Ichthyol Explor Freshw 6: 33-48.

Watson RE, Kottelat M. 1994. Lentipes whittenorum and Sicyopus auxilimentus, two new species of freshwater gobies from the western Pacific (Teleostei: Gobiidae: Sicydiinae). Ichthyol Explor Freshw 5 (4): 351-364.

Widodo MS, Hasan V, Mukti AT, Kusuma B. 2020. Distribution of Dwarf Snakehead Channa gachua Hamilton, 1822 (Teleostei, Channidae) on Brantas River Basin, Indonesia. Ecol Environ Conserv 26 (2): 618621.

Yamasaki N, Tachihara K. 2006. Reproductive biology and morphology of eggs and larvae of Stiphodon percnopterygionus (Gobiidae: Sicydiinae) collected from Okinawa island. Ichthyol Res 53: 12-18. DOI: $10.1007 / \mathrm{s} 10228-005-0307-1$. 